\title{
Analysis of deteriorative changes in seeds of cultivated rice under ambient storage condition
}

\author{
Jintu Sonuwal, Sharmila Dutta Deka* and Prakash Borah \\ Seed Science and Technology Program, Department of Plant Breeding and Genetics, \\ Assam Agricultural University, Jorhat 785013
}

\section{Article history:}

Received: 27 July, 2021

Revised: 18 Aug., 2021

Accepted: 02 Sept., 2021

\section{Citation:}

Sonuwal J, SD Deka* and P Borah. 2021. Analysis of deteriorative changes in seeds of cultivated rice under ambient storage condition. Journal of Cereal Research 13 (Spl-1): 28-36. http://doi.org/10.25174/25822675/2021/115289

"Corresponding author:

E-mail: sharmila9368@gmail.com

(C) Society for Advancement of Wheat and Barley Research

\section{Introduction}

Seed is the basic input of agricultural production system and a living entity which ages with time. After physiological maturity and over storage time, seed quality deteriorates due to different internal and external factors; therefore assessment of seed deterioration is required to predict the storage behaviour of any crop. Determination of deteriorative changes is essential to minimize the rate of deterioration, and its finale impact on seed production. In general the

\begin{abstract}
Seed deterioration is a serious problem where seeds are usually stored without adequate humidity and temperature control. In the present study storage potential of four different types of cultivated rice varieties viz Mahsuri (HYV), Bokul Bora (Local glutinous rice), Kola Joha (Local aromatic rice) and Ronga Sali (Local pigmented rice) has been evaluated under ambient storage condition based on different physiological and biochemical parameters. Effect of packaging material on the storability of the rice seeds was evaluated using three different types of packaging materials viz. Cloth bag, HDPE interwoven bag and HDPE bag (600gauges). The highest seed viability was maintained by seeds stored in HDPE Interwoven bag (100\%) by Ronga Sali followed by Bakul Bora (98.22\%), Mahshuri $(96.55 \%)$ and Kon Joha (97.89\%) and followed by HDPE bag. Among the tested varieties Kola Joha- an aromatic variety is found to be most sensitive and prone to deterioration. The estimated biochemical parameters indicate gradual changes in all the tested varieties with increase in storage period. Seeds stored in HDPE Interwoven bags had the highest mean $\alpha$-amylase activity $(0.390 \mu g)$ followed by the seeds stored in HDPE bags $(0.362 \mu \mathrm{g})$ and Cloth bags $(0.352 \mu \mathrm{g})$. Bokul Bora exhibited highest alpha amylase activity after storage of ten months and lowest was observed in Kola Joha indicating higher storage potential of the glutinous variety which is also assayed in the germination percentage and other vigour parameters. Variation in MDA content in tested rice varieties throughout the storage period indicates possibility of genetic factors associated with storability of different types of rice cultivars.
\end{abstract}

Keywords: packaging material, rice, seed deterioration, storage, viability. rate of deterioration is influenced by seed moisture, storage temperature, but genetic makeup of the seed is another important factor (Lee et al., 2019). It is also have dependency on pre and post harvest operation and environmental condition (Walters et al., 2010). However temperature, seed moisture content and relative humidity of the storage environment are major determinants of seed aging (Ellis et al., 1992, Rao et al., 2017). The aged seeds are reported to have 
lower germination and field emergence, with low vigour, hence susceptible to field stress conditions (Copeland and McDonald, 2001; Powell, 2012). Moreover, the seed reserve mobilization decreases with aging duration (Mohammadi $e t$ al., 2011).Genetic effect of seed aging has been reported in many studies. QTLs for seed longevity have been identified after natural aging in many crop species (Bentsink et al., 2000, Schwember and Bradford, 2010; Sasaki et al., 2005, Rao et al., 2017). While studies showed that proteins and enzymes are one of the major biomarker for seed longevity testing, several other studies have reported free radical-mediated lipid peroxidation, protein degradation, decrease in the activities of anti-oxidative enzymes, loosening of cellular membranes, and also damage to DNA integrity as major causes of seed deterioration (McDonald, 1999; Bailly, 2004; Zhang et al., 2021). Final consequences and extent of lipid peroxidation can be estimated through aldehydes including malondialdehyde (MDA) hence determination of MDA content is the conventional method for determination of lipid peroxidation (Sung and Jeng, 1994). Many studies confirmed the connection between MDA content in seed and storage period (Tian et al., 2008). During cereal seed germination, Alpha amylase in the aleurone layer plays an important role in hydrolyzing the endosperm starch into sugars, which is utilized for the growth of roots and shoots (Akazawa and Hara-Mishimura, 1985), hence it may be an indicator in determining deteriorative state.

Seed deterioration is a serious problem in countries where seeds are usually stored without adequate humidity and temperature control. It is also directly related to crop security and thereby food security of a country. Rice is primarily grown in tropical and sub-tropical climates where humidity is high due to high rainfall along with higher temperature. However, these climatic conditions are not favorable for storage of rice hence lead to rapid seed deterioration (Emam, 2007). Genetic variability for most of characters were reported in different types of rice by many other scientists (Thakur and Pandey 2020; Kaur et al., 2020) In the present study analysis of deteriorative pattern was investigated in regards to physiological and biochemical parameters and the functional indicators of deteriorative changes has been estimated using four different types of cultivated rice varieties.

\section{Materials and Methods}

\subsection{Experimental materials}

Rice varieties were selected from four different groups of rice viz. Mahsuri, Bokul Bora, Kola Joha, and Ronga Sali. Mashuri is a fine grained notified high yielding variety, characterized by brown husk colour, grain length and shape is long, medium and narrow and de-husked rice colour is white. Bokul Bora is a local glutinous rice variety characterized by brownish yellow husk and long and large grain type. Dehusked grain colour is yellowish, when cooked becomes sticky. Kola Joha is a popular aromatic local variety with husk colour black, grain type is short and round and length is medium. Coloured rice variety Ronga sali is with red husk colour, grain length is ranges from long to medium, and de-husked rice colour is red. Seeds of these varieties were collected just after Kharif harvest in the year 2018 .

\subsection{Storage condition and packaging materials}

Seeds were cleaned and sundried properly to bring the moisture content to $12 \%$ (Indian Minimum Seed Certification standard). Three different packaging materials were chosen based on available reports to conduct the storage study vizcloth bag, HDPE interwoven bags and HDPE (thickness 600 gauge) and five kg seeds of each variety were packed replicating thrice. Bags were stacked stored in ambient storage condition for ten Months. Meteorological data was recorded for the period and presented in the Fig. 1.

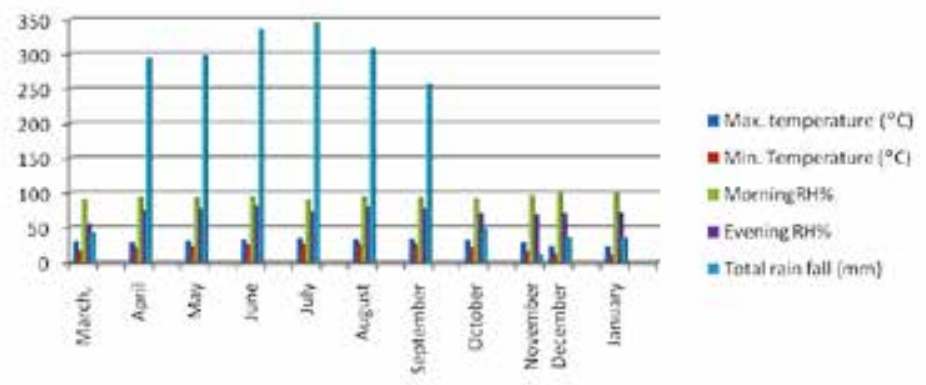

Fig. 1. Metrological observations during storage period 


\subsection{Observation procedure}

Seed quality parameters were evaluated at bimonthly intervals. Samples were drawn from each bag with minimum disturbance to the whole seeds stored.

\subsection{Seed viability testing}

Tetrazolium test was done following procedure given by Copeland and McDonald (2001). Germination percentage was calculated following (ISTA, 1999) with four replications of 100 seeds taken in each Petri- plates in seed germinator at $25^{\circ} \mathrm{C}$ temperature.

\subsection{Physiological quality testing}

Seedling vigour index was calculated with method given by Copeland and McDonald (1985). On $14^{\text {th }}$ day of germination test, the root and shoot length of the normal seedlings were measured and calculated the seedling vigour index as follows.

SVI $=$ Germination $\% \times$ Total average length of 10 normal seedlings $(\mathrm{cm})$.

Seedling dry weight was also calculated from the same sample over 10 seedlings / replication. Seed moisture content was tested by oven dry method following ISTA (1999) procedure. In electrical conductivity test using, three replications of 25 uninjured seeds of each treatment were placed in a $100 \mathrm{ml}$ beaker and $75 \mathrm{ml}$ of de-ionized water was added and placed at the constant temperature of $25^{\circ} \mathrm{C}$ for 24 hours in an incubator (Gupta, 1993). The electrical conductivity of each replication was measured by using a digital conductivity meter (Model ConductivityTDS Meter 308, Company Systronics, and India) and expressed in milliohms $\mathrm{cm}^{-1} \mathrm{gm}^{-1}$.

\subsection{Biochemical quality testing}

Soluble protein content was estimated following Lowry et al. 1951, total free amino acid content was estimated following procedure given by Moore and Stein, 1948. To study the enzymatic activity, procedure described by Khan and Faust (1967) was followed to estimate $\alpha$-amylase enzyme activity. Lipid peroxidation was determined as the concentration of thiobarbituric acid (TBA), equated with malonaldeyde (MDA). MDA content was determined by the TBA reaction (Hendry et al., 1993).

\subsection{Statistical analysis}

The data recorded for each parameter were subjected to analysis of variance (ANOVA), following the method suggested by Gomez and Gomez (1984). The significance and non-significance of the given variance were determined by calculating the respective values of $\mathrm{F}$ and by comparing the calculated $\mathrm{F}$ values with corresponding tabulated $\mathrm{F}$ value of $5 \%$ level of probability and significantly different treatment means were compared by the method of Least Significance Difference (LSD).

\section{Results and Discussion}

\subsection{Storage effect on indicators of seed viability}

In the present study, the results of tetrazolium test and germinations were taken as indicator of seed viability. The results of terazolium test indicates that the seed viability declined at minimum rate during entire storage duration for all varieties and in all the tested packaging materials (Table 1). Seed viability declined more rapidly in cloth bags and HDPE bags as compared to HDPE interwoven bag as the storage duration advanced. The highest seed viability was maintained by seeds stored in HDPE Interwoven bag (100 \%) by Ronga Sali followed by Bakul Bora (98.22 \%), Mahshuri (96.55 \%) and Kon Joha $(97.89 \%)$ and followed by HDPE bag. Significant effect of seed storage duration and packaging materials was also observed on germination of the tested varieties (Table 2). However, the seed germination percentage was at certification level irrespective of varieties until fourth months of storage $(>80 \%)$. Highest viability in Ronga Sali indicates probable role of anthocyanin, an antioxidant might have a role in keeping viability by minimising affects of Reactive oxygen Species (ROS). Role of antioxidant on seed viability has been reported in earlier studies (Govindaraj et al., 2017). Two moisture semi-pervious packaging materials were found to more suitable than the cloth bag. However performance of HDPE interwoven bag is superior over other two. Variation for seed viability in different types of indica rice varieties has been reported various studies (Lee $e t$ al., 2019; Bakhtavar and Afzal, 2020). 
Table 1. Effect of storage duration, variety and packaging materials on seed viability (\%)(Tetrazolium test) of rice varieties

\begin{tabular}{|c|c|c|c|c|c|c|c|c|c|c|c|c|}
\hline \multirow{3}{*}{$\begin{array}{c}\text { Storage } \\
\text { Duration/ } \\
\text { Variety/ } \\
\text { Packaging } \\
\text { Material } \\
\text { March } \\
\text { (Initial) }\end{array}$} & \multicolumn{3}{|c|}{ Mahsuri } & \multicolumn{3}{|c|}{ Bokul Bora } & \multicolumn{3}{|c|}{ Kola Joha } & \multicolumn{3}{|c|}{ Ronga Sali } \\
\hline & $\begin{array}{c}\text { Cloth } \\
\text { Bag }\end{array}$ & $\begin{array}{c}\text { HDPE } \\
\text { Interwoven } \\
\text { Bag }\end{array}$ & $\begin{array}{c}\text { HDPE } \\
\text { Bag }\end{array}$ & $\begin{array}{c}\text { Cloth } \\
\text { Bag }\end{array}$ & $\begin{array}{c}\text { HDPE } \\
\text { Interwoven } \\
\text { Bag }\end{array}$ & $\begin{array}{c}\text { HDPE } \\
\text { Bag }\end{array}$ & $\begin{array}{c}\text { Cloth } \\
\text { Bag }\end{array}$ & $\begin{array}{c}\text { HDPE } \\
\text { Interwoven } \\
\text { Bag }\end{array}$ & $\begin{array}{c}\text { HDPE } \\
\text { Bag }\end{array}$ & $\begin{array}{c}\text { Cloth } \\
\text { Bag }\end{array}$ & $\begin{array}{c}\text { HDPE } \\
\text { Interwoven } \\
\text { Bag }\end{array}$ & $\begin{array}{c}\text { HDPE } \\
\text { Bag }\end{array}$ \\
\hline & 100.00 & 100.00 & 100.00 & 100 & 100.00 & 100.00 & 100.00 & 100.00 & 100 & 100 & 100 & 100 \\
\hline May & 97.33 & & & 100 & & 98 & 96.67 & & 98.00 & 98.67 & 100 & 97.33 \\
\hline July & 96.00 & 94.00 & 92.67 & 98.00 & 96.67 & 94.67 & 97.33 & 98.67 & 95.33 & 96.67 & 100 & 94.00 \\
\hline September & 90.00 & 91.33 & 90.00 & 94.00 & 99.33 & 91.33 & 90.00 & 96.00 & 90.67 & 86.67 & 100 & 93.33 \\
\hline November & 88.00 & 100.00 & 8 & 87.33 & 98.00 & 8 & 86.67 & 96.67 & 90.00 & 84.00 & 100 & 87.33 \\
\hline January & 80.67 & 96.00 & 80.67 & 80.00 & 100 & 80.67 & 81.33 & 98.00 & 84.00 & 80.67 & 100 & 80.67 \\
\hline Mean & 92.00 & 96.55 & 91.11 & 93.22 & 98.22 & 91.89 & 92.00 & 97.89 & 93.00 & 91.11 & 100 & 92.11 \\
\hline
\end{tabular}

$\mathrm{CD}_{0.05} 0.281$ (Variety)

$\mathrm{CD}_{0.05} 0.488$ (Interaction Variety X Packaging Material)

$\mathrm{CD}_{0.05} 0.689$ (Interaction Variety X Storage Duration )

$\mathrm{CD}_{0.05} 0.597$ (Interaction Storage Duration X Packaging Material)

Table 2. Storage Performance of rice varieties based on germination percentage (\%) in ambient condition

\begin{tabular}{|c|c|c|c|c|c|c|c|c|c|c|c|c|}
\hline \multirow{2}{*}{$\begin{array}{c}\text { Storage } \\
\text { Duration/ } \\
\text { Variety/ } \\
\text { Packaging } \\
\text { Material } \\
\end{array}$} & \multicolumn{3}{|c|}{ Mahsuri } & \multicolumn{3}{|c|}{ Bokul Bora } & \multicolumn{3}{|c|}{ Kola Joha } & \multicolumn{3}{|c|}{ Ronga Sali } \\
\hline & $\begin{array}{c}\text { Cloth } \\
\text { Bag }\end{array}$ & $\begin{array}{c}\text { HDPE } \\
\text { Interwoven } \\
\text { Bag } \\
\end{array}$ & $\begin{array}{c}\text { HDPE } \\
\text { Bag }\end{array}$ & $\begin{array}{c}\text { Cloth } \\
\text { Bag }\end{array}$ & $\begin{array}{c}\text { HDPE } \\
\text { Interwoven } \\
\text { Bag } \\
\end{array}$ & $\begin{array}{c}\text { HDPE } \\
\text { Bag }\end{array}$ & $\begin{array}{c}\text { Cloth } \\
\text { Bag }\end{array}$ & $\begin{array}{c}\text { HDPE } \\
\text { Interwoven } \\
\text { Bag } \\
\end{array}$ & $\begin{array}{c}\text { HDPE } \\
\text { Bag }\end{array}$ & $\begin{array}{c}\text { Cloth } \\
\text { Bag }\end{array}$ & $\begin{array}{c}\text { HDPE } \\
\text { Interwoven } \\
\text { Bag } \\
\end{array}$ & $\begin{array}{c}\text { HDPE } \\
\text { Bag }\end{array}$ \\
\hline March (Initial) & 90.67 & 90.67 & 90.67 & 87.33 & 87.33 & 87.33 & 86.33 & 86.33 & 86.33 & 88.33 & 88.33 & 88.33 \\
\hline May & 86.33 & 88.00 & 87.00 & 85.67 & 87.00 & 86.00 & 84.00 & 85.00 & 84.33 & 84.00 & 88.00 & 85.67 \\
\hline July & 84.00 & 86.33 & 85.33 & 82.00 & 87.00 & 84.00 & 81.00 & 86.00 & 82.00 & 81.00 & 88.00 & 83.00 \\
\hline September & 82.00 & 86.00 & 83.00 & 79.00 & 86.00 & 80.00 & 78.33 & 85.00 & 80.33 & 78.00 & 87.00 & 80.00 \\
\hline November & 76.00 & 86.00 & 79.33 & 77.67 & 87.00 & 78.00 & 73.00 & 85.00 & 74.67 & 75.00 & 87.00 & 77.67 \\
\hline January & 64.00 & 84.00 & 70.00 & 62.00 & 86.00 & 74.00 & 61.67 & 83.00 & 71.00 & 70.00 & 87.00 & 75.33 \\
\hline Mean & 80.5 & 86.83 & 82.56 & 78.95 & 86.72 & 81.56 & 77.39 & 85.06 & 79.78 & 79.39 & 87.55 & 81.67 \\
\hline
\end{tabular}

$\mathrm{CD}_{0.05} 0.296$ (Variety)

$\mathrm{CD}_{0.05}{ }_{0.513}$ (Interaction Variety X Packaging Material)

$\mathrm{CD}_{0.05} 0.725$ (Interaction Variety X Storage Duration)

$\mathrm{CD}_{0.05}{ }^{0.628}$ (Interaction Storage Duration X Packaging Material)

\subsection{Storage effect on Physiological Indicators}

Seed storage duration and packaging materials had significant effect on moisture content of the observed varieties (Fig 2). The moisture percentage of the varieties increased with increasing seed storage duration (up-to July) during initial periods and then declined during later period (from September onwards). Highest mean moisture percentage observed in the month of July (13.17-13.95 \%) in cloth bag followed by HDPE bags and then moisture percentage was declined gradually indicating role of atmospheric humidity and temperature on seed moisture content (Fig 2). Equilibrium moisture content (EMS) of seed is directly related to seed micro environment. HDPE inter woven bags allows migration of seed moisture and its minimum entry into bags enables the seed to maintain moisture content. Thus proves to be a betters packaging material in relation to maintenance of better seed quality characters. Seeds sensitivity to high temperatures is strongly dependent on their water content, loss of viability being higher with increasing moisture percentage (Kibinza

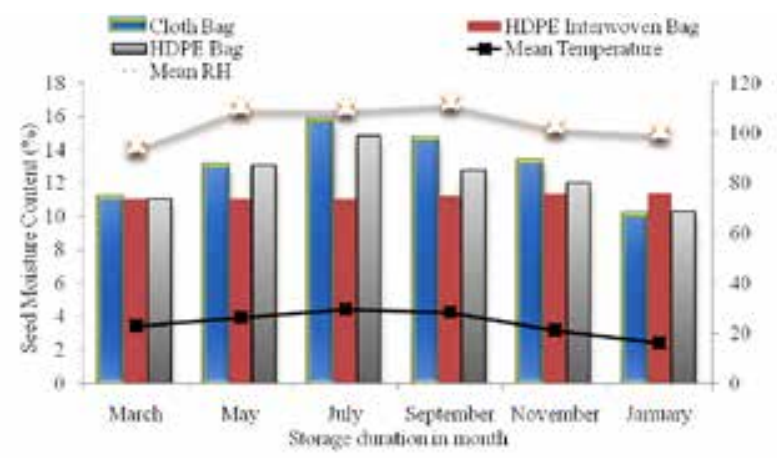

Fig. 2. Interactive effect of storage duration and packaging materials on seed moisture content $(\%)$ in rice varieties 
et al., 2006, Bradford et al 2016). Thus, moisture plays a vital role in seed quality.

While estimating seed vigour indicators, seedling dry weight of all the varieties declined as the seed storage duration increases (Fig 3). The rate of decline was found slower and gradual till six months of storage, later which became sharp with longer storage duration. Variation for seedling dry weight was statistically significant among the all varieties with respect to packaging materials. Similar reports are available in several studies (Finch-Savage and Bassel, 2016).

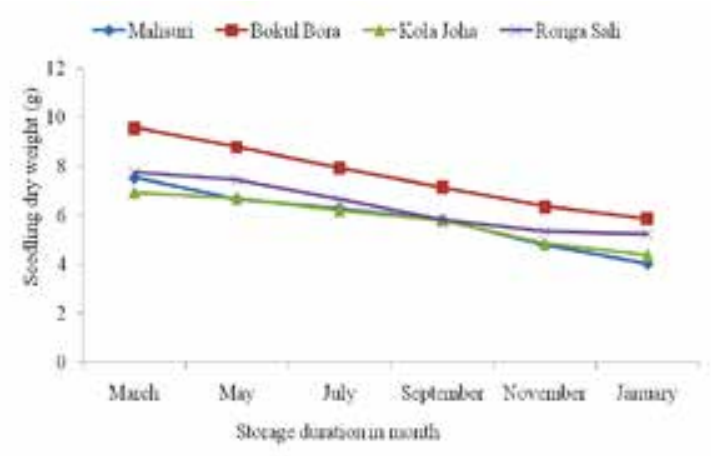

Fig. 3. Interactive effect of variety and storage duration on seedling dry weight $(\mathrm{g})$ in rice varieties

The electrical conductivity of the varieties indicated an increasing trend as the seed storage duration increases (Fig 4). The lowest mean electrical conductivity was observed in the variety Mahsuri $(0.096 \mathrm{mmho} / \mathrm{cm} / \mathrm{gm})$ followed by varieties such as Bokul Bora $(0.124 \mathrm{mmho} / \mathrm{cm} / \mathrm{gm})$, Ronga Sali $(0.128 \mathrm{mmho} / \mathrm{cm} / \mathrm{gm})$ and Kola Joha $(0.177 \mathrm{mmho} / \mathrm{cm} /$ $\mathrm{gm})$. The Mahsuri is a high yielding variety therefore it might have genetic advantage of higher integrity of seed coat membrane and lesser EC value. Other studies also reported that electric conductivity in dehulled seeds was effective to identify vigour differences of genotypes in storage conditions (Szemruch 2016).

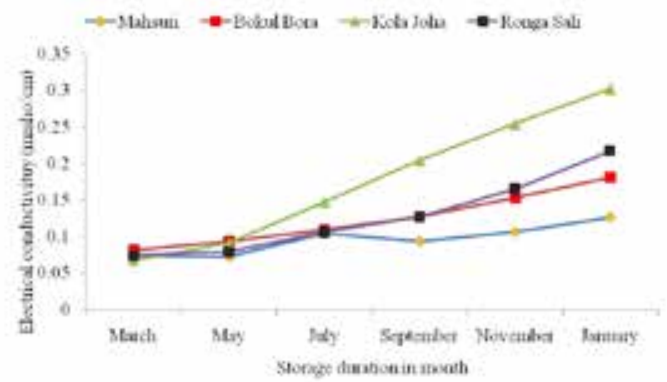

Fig. 4. Interactive effect of variety and storage duration on electrical conductivity $(\mathrm{mmho} / \mathrm{cm})$ in rice varieties

\subsection{Storage effects on biochemical indicators}

The soluble protein content of the varieties decreased with increasing seed storage duration. The rate of decrease was slow and gradual till the last month of storage (January) (Table 3). Highest soluble protein content was recorded in the variety Mahsuri (13.21 \%) followed by Ronga Sali (10.33 \%), Bokul Bora (8.71 \%) and Kola Joha (6.89 \%). Variation for soluble protein content was statistically significant for all the storage duration with respect to variety. However, the rate of increase of total free amino acid was very slow and gradual till the last month of storage (Table 4). The total free amino acid content was recorded higher in the variety Bokul Bora (1.012 \%) followed by Ronga Sali (0.616 \%), Kola Joha $(0.595 \%)$ and Mahsuri $(0.574 \%)$. There are similar reports on biochemical changes associated with seed ageing (Rajjou et al., 2012).Many studies confirmed the connection between increased MDA content in seed and prolonged storage period, as well as the application of artificial seed aging (Tian et al., 2008). Highest MDA content in Bokul bora seed compared to other three tested varieties, on $10^{\text {th }}$ month of the storage period (Fig 5), lowest was observed in Ronga Sali. The variation in biochemical indicators indicates possibility of genetic factors associated with storability of different group of rice. The present study also conforms to the earlier reports on this direction (Wang et al., 2018).

Table 3. Effect of storage duration, variety and packaging materials on soluble protein content (\%) of rice varieties

\begin{tabular}{cccccccccccccc}
\hline $\begin{array}{c}\text { Storage } \\
\text { Duration/ } \\
\begin{array}{c}\text { Variety/ } \\
\text { Packaging } \\
\text { Material }\end{array}\end{array}$ & $\begin{array}{c}\text { Cloth } \\
\text { Bag }\end{array}$ & $\begin{array}{c}\text { Mahsuri } \\
\text { Interwoven } \\
\text { Bag }\end{array}$ & $\begin{array}{c}\text { HDPE } \\
\text { Bag }\end{array}$ & $\begin{array}{c}\text { Cloth } \\
\text { Bag }\end{array}$ & $\begin{array}{c}\text { Bnterwoven } \\
\text { Bag }\end{array}$ & $\begin{array}{c}\text { HDPE } \\
\text { Bag }\end{array}$ & $\begin{array}{c}\text { Cloth } \\
\text { Bag }\end{array}$ & $\begin{array}{c}\text { HDPE } \\
\text { Interwoven } \\
\text { Bag }\end{array}$ & $\begin{array}{c}\text { HDPE } \\
\text { Bag }\end{array}$ & $\begin{array}{c}\text { Cloth } \\
\text { Bag }\end{array}$ & $\begin{array}{c}\text { HDPE } \\
\text { Interwoven } \\
\text { Bag }\end{array}$ & $\begin{array}{c}\text { HDPE } \\
\text { Bag }\end{array}$ \\
\hline $\begin{array}{c}\text { March } \\
\text { (Initial Data) }\end{array}$ & 13.21 & 13.21 & 13.21 & 8.71 & 8.71 & 8.71 & 6.89 & 6.89 & 6.89 & 10.33 & 10.33 & 10.33 \\
May & 13.32 & 13.32 & 13.21 & 8.70 & 8.67 & 8.71 & 6.84 & 6.87 & 6.84 & 10.33 & 10.33 & 10.34 \\
July & 13.17 & 13.19 & 13.12 & 8.54 & 8.69 & 8.68 & 6.81 & 6.84 & 6.79 & 10.13 & 10.23 & 10.19 \\
September & 12.84 & 13.23 & 12.69 & 8.14 & 8.67 & 8.14 & 6.63 & 6.83 & 6.53 & 9.47 & 10.33 & 9.50 \\
\hline
\end{tabular}


Deteriorative changes in seeds of cultivated rice

\begin{tabular}{ccccccccccccc}
\hline November & 11.84 & 13.23 & 12.14 & 7.27 & 8.67 & 7.57 & 6.14 & 6.81 & 6.18 & 9.26 & 10.33 & 9.39 \\
January & 10.33 & 13.14 & 11.32 & 6.87 & 8.65 & 7.17 & 5.18 & 6.61 & 5.33 & 8.34 & 10.23 & 9.05 \\
\hline Mean. & 12.45 & 13.22 & 12.62 & 8.04 & 8.68 & 8.16 & 6.42 & 6.81 & 6.43 & 9.64 & 10.30 & 9.80 \\
\hline
\end{tabular}

$\mathrm{CD}_{0.05} 0.018$ (Variety)

$\mathrm{CD}_{0.05} 0.031$ (Interaction Variety X Packaging Material)

$\mathrm{CD}_{0.05} 0.043$ (Interaction Variety X Storage Duration)

$\mathrm{CD}_{0.05} 0.038$ (Interaction Storage Duration X Packaging Material)

Table 4: Effect of storage duration, variety and packaging materials on total free amino acid content ( $\%)$ of rice varieties

\begin{tabular}{|c|c|c|c|c|c|c|c|c|c|c|c|c|}
\hline \multirow{2}{*}{$\begin{array}{c}\text { Storage } \\
\text { Duration/ } \\
\text { Variety/ } \\
\text { Packaging } \\
\text { Material }\end{array}$} & \multicolumn{3}{|c|}{ Mahsuri } & \multicolumn{3}{|c|}{ Bokul Bora } & \multicolumn{3}{|c|}{ Kola Joha } & \multicolumn{3}{|c|}{ Ronga Sali } \\
\hline & $\begin{array}{c}\text { Cloth } \\
\text { Bag }\end{array}$ & $\begin{array}{c}\text { HDPE } \\
\text { Interwoven } \\
\text { Bag } \\
\end{array}$ & $\begin{array}{c}\text { HDPE } \\
\text { Bag }\end{array}$ & $\begin{array}{c}\text { Cloth } \\
\text { Bag }\end{array}$ & $\begin{array}{c}\text { HDPE } \\
\text { Interwoven } \\
\text { Bag } \\
\end{array}$ & $\begin{array}{c}\text { HDPE } \\
\text { Bag }\end{array}$ & $\begin{array}{c}\text { Cloth } \\
\text { Bag }\end{array}$ & $\begin{array}{c}\text { HDPE } \\
\text { Interwoven } \\
\text { Bag } \\
\end{array}$ & $\begin{array}{c}\text { HDPE } \\
\text { Bag }\end{array}$ & $\begin{array}{c}\text { Cloth } \\
\text { Bag }\end{array}$ & $\begin{array}{c}\text { HDPE } \\
\text { Interwoven } \\
\text { Bag } \\
\end{array}$ & $\begin{array}{c}\text { HDPE } \\
\text { Bag }\end{array}$ \\
\hline $\begin{array}{c}\text { March } \\
\text { (Initial Data) }\end{array}$ & 574 & 0.574 & 0.574 & 1.012 & 1.012 & 1.012 & 0.595 & 0.595 & 0.595 & 0.616 & 0.616 & 0.616 \\
\hline May & 0.593 & 0.563 & 0.580 & 1.013 & 1.02 & 1.04 & 0.625 & 0.630 & 0.620 & 0.614 & 0.607 & 0.630 \\
\hline July & 0.630 & 0.583 & 0.607 & 1.077 & 1.023 & 1.143 & 0.693 & 0.583 & 0.680 & 0.621 & 0.630 & 0.623 \\
\hline Sept. & 0.680 & 0.587 & 0.630 & 1.23 & 1.02 & 1.037 & 0.730 & 0.593 & 0.717 & 0.730 & 0.623 & 0.687 \\
\hline Nov. & 0.713 & 0.613 & 0.670 & 1.353 & 1.047 & 1.143 & 0.793 & 0.627 & 0.767 & 0.747 & 0.620 & 0.733 \\
\hline January & 0.840 & 0.637 & 0.770 & 1.907 & 1.063 & 1.42 & 0.963 & 0.663 & 0.837 & 0.873 & 0.643 & 0.770 \\
\hline Mean & 0.672 & 0.593 & 0.639 & 1.265 & 1.031 & 1.133 & 0.733 & 0.615 & 0.703 & 0.700 & 0.623 & 0.677 \\
\hline
\end{tabular}

$\mathrm{CD}_{0.05} 0.004$ (Variety)

$\mathrm{CD}_{0.05}^{0.05} 0.007$ (Interaction Variety X Packaging Material)

$\mathrm{CD}_{0.05}^{0.05} 0.010$ (Interaction Variety X Storage Duration)

$\mathrm{CD}_{0.05}^{0.05} 0.009 \mathrm{~S}$ (Interaction Storage Duration X Packaging Material)

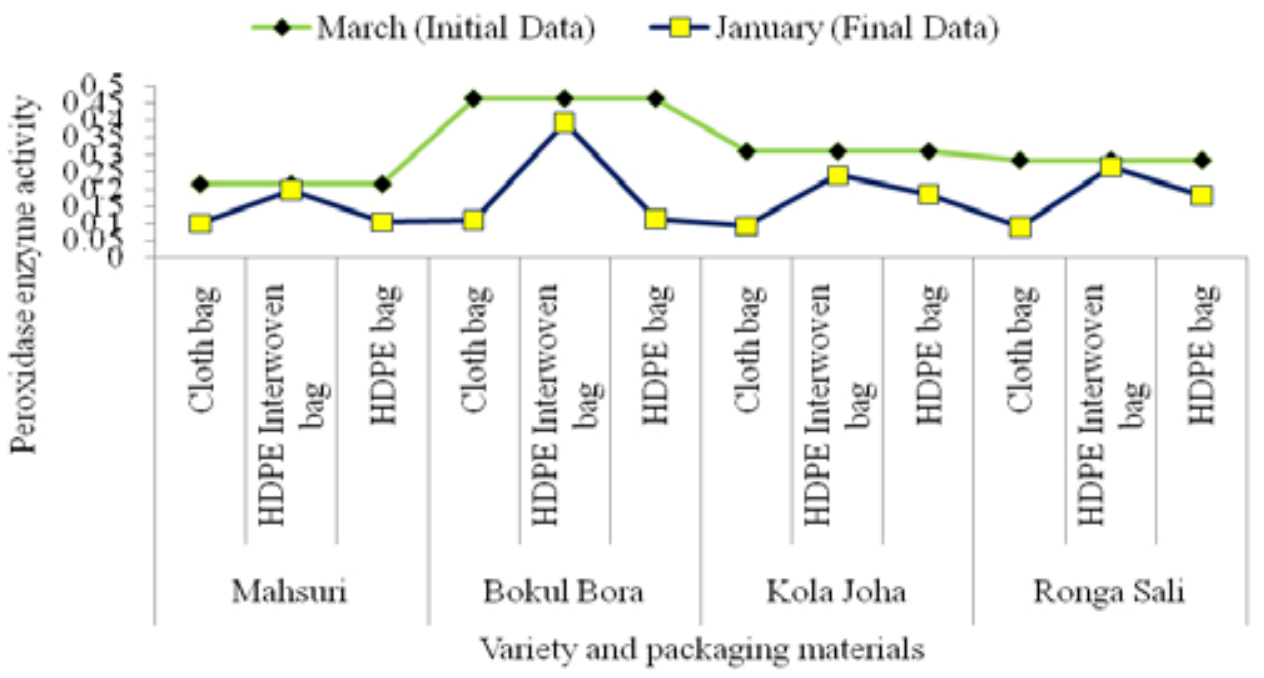

Fig. 5. Effect of storage duration, variety and packaging materials on (MDA) enzyme activity (absorbance) of rice varieties

The rate of $\alpha$-amylase activity was decline gradually during entire experimental period (Table 5). The $\alpha$-amylase activity was observed highest in the variety Bokul Bora $(0.564 \mu \mathrm{g})$ followed by Mahsuri $(0.435 \mu \mathrm{g})$, Ronga Sali $(0.413 \mu \mathrm{g})$ and Kola Joha $(0.157 \mu \mathrm{g})$. Packaging materials had significant effect on $\alpha$-amylase activity of the observed varieties, of which the seeds stored in HDPE Interwoven bags had the highest mean $\alpha$-amylase activity $(0.390 \mu \mathrm{g})$ followed by the seeds stored in HDPE bags $(0.362 \mu \mathrm{g})$ and Cloth bags $(0.352 \mu \mathrm{g})$. Kavitha et al. (2017) reported a significantly higher $\alpha$-amylase enzyme activity in fresh seeds of peanut and the values progressively decreased over the period of natural ageing. 
Table 5. Effect of storage duration, variety and packaging materials on alpha amylase enzyme activity $(\mu \mathrm{g})$ of rice varieties

\begin{tabular}{lcccccccccccccc}
\hline $\begin{array}{c}\text { Storage } \\
\text { Duration/ } \\
\begin{array}{c}\text { Variety/ } \\
\text { Packaging } \\
\text { Material }\end{array}\end{array}$ & $\begin{array}{c}\text { Cloth } \\
\text { Bag }\end{array}$ & $\begin{array}{c}\text { Mahsuri } \\
\text { Interwoven } \\
\text { Bag }\end{array}$ & $\begin{array}{c}\text { HDPE } \\
\text { Bag }\end{array}$ & $\begin{array}{c}\text { Cloth } \\
\text { Bag }\end{array}$ & $\begin{array}{c}\text { BDPE } \\
\text { Interwoven } \\
\text { Bag }\end{array}$ & $\begin{array}{c}\text { HDPE } \\
\text { Bag }\end{array}$ & $\begin{array}{c}\text { Cloth } \\
\text { Bag }\end{array}$ & $\begin{array}{c}\text { Hola Joha } \\
\text { Interwoven } \\
\text { Bag }\end{array}$ & $\begin{array}{c}\text { HDPE } \\
\text { Bag }\end{array}$ & $\begin{array}{c}\text { Cloth } \\
\text { Bag }\end{array}$ & $\begin{array}{c}\text { HDPE } \\
\text { Interwoven } \\
\text { Bag }\end{array}$ & $\begin{array}{c}\text { HDPE } \\
\text { Bag }\end{array}$ \\
\hline $\begin{array}{l}\text { March } \\
\text { (Initial Data) }\end{array}$ & 0.435 & 0.435 & 0.435 & 0.564 & 0.564 & 0.564 & 0.157 & 0.157 & 0.157 & 0.413 & 0.413 & 0.413 \\
May & 0.435 & 0.436 & 0.435 & 0.555 & 0.562 & 0.553 & 0.156 & 0.156 & 0.155 & 0.411 & 0.412 & 0.422 \\
July & 0.434 & 0.435 & 0.433 & 0.542 & 0.564 & 0.552 & 0.146 & 0.157 & 0.153 & 0.410 & 0.414 & 0.407 \\
September & 0.399 & 0.431 & 0.408 & 0.501 & 0.562 & 0.513 & 0.132 & 0.149 & 0.141 & 0.391 & 0.411 & 0.394 \\
November & 0.344 & 0.429 & 0.377 & 0.465 & 0.563 & 0.493 & 0.115 & 0.148 & 0.121 & 0.334 & 0.412 & 0.357 \\
January & 0.304 & 0.423 & 0.335 & 0.395 & 0.565 & 0.432 & 0.098 & 0.149 & 0.102 & 0.304 & 0.414 & 0.324 \\
\hline Mean & 0.392 & 0.432 & 0.404 & 0.504 & 0.563 & 0.518 & 0.134 & 0.153 & 0.138 & 0.377 & 0.413 & 0.386 \\
\hline
\end{tabular}

$\mathrm{CD}_{0.05} 0.010$ (Variety)

$\mathrm{CD}_{0.05}^{0.05} 0.018$ (Interaction Variety X Packaging Material)

$\mathrm{CD}_{0.05} 0.026$ (Interaction Variety X Storage Duration)

$\mathrm{CD}_{0.05} 0.022$ (Interaction Storage Duration X Packaging Material)

\section{Conclusion}

From the above discussion we can conclude that there is significant impact of genetic background on seed ageing process. Bakul bora and Roga Sali from the traditional glutinous rice group and pigmented rice group exhibited better storability while considering all the physiological and biochemical indicators than rest of the varieties, therefore may be a source of genetic material in breeding for better storage life of rice varieties. It also indicates probable role of anthocyanin colouration in maintenance seed viability and warrants further investigation in future research programs. Understanding seed deterioration pattern is necessary for successful planning of storage needs of seeds. For controlling, predicting, and maintaining seed viability a detailed study on genetics is required to improve the cultivars for better storability.

\section{Acknowledgements}

The present work has been done as a part of project work funded by Department of Biotechnology, Govt of India. The authors acknowledge the same.

\section{Conflict of Interest}

Authors declare that they have no conflict of interest.

\section{Ethical Compliance Statement}

NA

\section{Author's Contribution}

Conceptualization of research (SDD); Designing of the experiments (SDD); Contribution of experimental materials (SDD,JS,PB); Execution of field/lab experiments and data collection (JS)

\section{References}

1. Akazawa T and I Hara-Mishimura. 1985. Topographic aspects of biosynthesis, extracellular section and intracellular storage of proteins in plant cells. Annual Review of Plant Physiology 70: 441-472

2. Bailly C. 2004. Active oxygen species and antioxidants in seed biology. Seed Science Research 14: 93-107.

3. Bakhtavar M.A. and I Afzal. 2020. Seed Storage and Longevity: Mechanism, types and management. In: Tiwari A.K. (eds) Advances in Seed Production and Management. Springer, Singapore. https://doi. org/10.1007/978-981-15-4198-8_21

4. Bentsink L, C Alonso-Blanco, D Vreugdenhil, K Tesnier, SPC Groot and M Koornneef. 2000. Genetic analysis of seed-soluble oligosaccharides in relation to seed storability of Arabidopsis. Plant Physiology 124: 1595-1604

5. Bradford Kent J, P Dahal, and P Bello. 2016. Using relative humidity indicator paper to measure seed and commodity moisture contents. Agricultural and Environmental Letters 1(1):1-4

6. Copeland, C and MB McDonald. 1985. Principles of Seed Science and Technology Michigan and Ohio State Universities. Minneapolis: Burgess, second edition, pp. 321 
7. Copeland, LO and MB McDonald. 2001. Principles of Seed Science and Technology, Kluwer academic publishers, Boston, pp. 330.

8. Ellis, RH, TD Hong, and EH Roberts. 1992. Low moisture content limit to the negative logarithmic relation between seed longevity and moisture content in three sub-species of rice. Annals of Botany 69: 53-58.

9. Emam Y. 2007. Cereal Production, 3rd ed. Shiraz, Iran: Shiraz University Press. p. 190

10. Finch-Savage WE and GW Basse. 2016. Seed vigour and crop establishment: extending performance beyond adaptation. Journal of Experimental Botany, 67: 567-591.

11. Govindaraj M P, V Masilamani, A Albert and M Bhaskaran. 2017. Role of antioxidant in seed qualityA review. Agricultural Reviews, 38(3): 180-190.

12. Gomez, KA and AA Gomez. 1984. Statistical procedures for agricultural research (2 ed.). John wiley and sons, New York, 680.

13. Gupta, P C. 1993. Seed vigour testing. In: Handbook of seed testing (Ed. Agrawal, P.K.). DAC, Ministry of Agriculture, Govt. of India, New Delhi, pp 242-249.

14. Hendry, GAF, PC Thorpe and MN Merzlyak. 1993. Stress indicators: Lipid peroxidation. In: Hendry, GAF and JP Grime (eds.) Methods in Comparative Plant Ecology, pp. 154-6. Chapman and Hall, London.

15. International Seed Testing Association 1995. Handbook of Vigour Test Methods. $3^{\text {rd }}$ edition. International Seed Testing Association. Zurich. Switzerland.

16. Kavitha S, C Menaka and M Ananthi. 2017. Deterioration in sesame (Sesamum indicum L.) under natural and accelerated ageing. International Journal of Chemical Studies 5(4): 1141-1146

17. Kaur Y, R Kaur, R Khanna and N Sidhu. 2020. Assessment of genetic diversity in a set of rice (Oryza sativa L.) genotypes using molecular marker. Journal of Cereal Research 12(3): 327-333.

18. Khan AA and MA Faust. 1967. Effect of growth retardants on alpha-amylase production in germinating barley seeds. Physiologia Plantarum 20: 673-681.

19. Kibinza S, D Vinel, D Côme, C Bailly and F Corbineau. 2006. Sunflower seed deterioration as related to moisture content during ageing, energy metabolism and active oxygen species scavenging. Physiologia Plantarum 128 (3): 496-506.

20. Lee JS, M Velasco-Punzalan, M Pacleb, R Valdez, T Kretzschmar, KL McNally, AM Ismail, PC Cruz, NR Sackville Hamilton and FR Hay. 2019. Variation in seed longevity among diverse Indica rice varieties, Annals of Botany 124: 447-460, https:// doi.org/10.1093/aob/mcz093

21. Lowry Oh, NJ Rosebrough, AL Farr and RJ Randall. 1951. Protein measurement with the Folin phenol reagent. Journal of Biological Chemistry 193(1): 265-75.

22. McDonald MB. 1975. A review and evaluation of seed vigor tests. Proceedings of the Association of Official Seed Analysts 65:109-139.

23. McDonald, MB. (1999). Seed deterioration: Physiology, repair and assessment. Seed Science and Technology 27:177-237.

24. Mohammadi H, A Soltani, HR Sadeghipour and E Zeinali. 2011. Effects of seed aging on subsequent seed reserve utilization and seedling growth in soybean International Journal of Plant Production 5:65-70.

25. Moore, S and WH Stein. 1948. Photometric ninhydrin method for use in the chromatography of amino acids. Journal of Biological Chemistry 176: 367388 .

26. Powell AA and S Matthews. 2012. Seed aging/ repair hypothesis leads to new testing methods. Seed Technology 34, 15-25

27. Rajjou L, M Duval, K Gallardo, J Catusse and J Bally. 2012. Seed germination and vigor. Annual Review of Plant Biology 63: 507-533.

28. Rao NK, ME Dulloo and JM Engels. 2017. A review of factors that influence the production of quality seed for long-term conservation in genebanks. Genetic Resources and Crop Evolution 64, 1061-1074.

29. Sasaki K, Y Fukuta and T Sato. 2005. Mapping of quantitative trait loci controlling seed longevity of 
rice (Oryza sativa L.) after various periods of seed storage. Plant Breeding 124: 361-366

30. Schwember AR and KJ Bradford. 2010. Quantitative trait loci associated with longevity of lettuce seeds under conventional and controlled deterioration storage conditions. Journal of Experimental Botany 61: 4423-4436

31. Sung JM and TL Jeng. 1994. Lipid peroxidation and peroxide-scavenging enzymes associated with accelerated aging of peanut seed. Plant Physiology 91: 51-55.

32. Szemruch C, OD Longo, L Ferrari, S Renteria, M Murcia, M Cantamutto and D Rondanini. 2015. Ranges of vigor based on the electrical conductivity test in dehulled sunflower seeds Research Journal of Seed Science 8 (1): 12-21

33. Tian X, S Song and Y Lei. 2008. Cell death and reactive oxygen species metabolism during accelerated ageing of soybean axes. Russian Journal of Plant Physiology 55(1): 33-40.
34. Thakur D and DP Pandey. 2020. Genetic variability for yield and quality traits in local germplasm of rice of Himachal Pradesh. Journal of Cereal Research 12(2): 157-159.

35. Walters C, D Ballesteros and VA Vertucci. 2010. Structural mechanics of seed deterioration: Standing the test of time. Plant Science 179: 565-573.

36. Wang W, A He, S Peng, J Huang, K Cui and L Nie. 2018. The effect of storage condition and duration on the deterioration of primed rice seeds. Frontiers in plant science 9:172.

37. Zhang K,Y Zhang, J Sing, J Song and JT Meng. 2021. Deterioration of orthodox seeds during ageing: Influencing factors, physiological alterations and the role of reactive oxygen species. Plant Physiology and Biochemistry 158: 475-485. 